\title{
КУЛТУРНИ И НАЦИОНАЛНИ ИДЕНТИТЕТ ЈУГОСЛОВЕНСКЕ ОМЛАДИНЕ У ОГЛЕДАЛУ АНАЛИТИЧКЕ БИБЛИОГРАФИЈЕ ОМЛАДИНСКЕ МЕЂУРАТНЕ ПЕРИОДИКЕ 2
}

\section{Сажетак}

Докторска дисетрација Омладинска међуратна периодика - студија и библиографија представља научној и стручној јавности непроцењиво богатство информација о животу и раду младих људи тога доба. У њој су хронолошки, формално и садржајно представљени сви доступни наслови омладинске међуратне периодике на српско-хрватском језику. Аналитичка и анотирана библиографија омладинске међуратне периодике је допринела употпуњавању националне аналитичке библиографије.

Кључне речи: омладинска периодика, аналитичка библиографија, југословенска идеја, национални идентитет

\section{Увод}

По окончању Великог рата на територији новоосноване Краљевине СХС покренуто је око 150 наслова омладинске периодике различите тематике што показује жељу младих да јавно изнесу своје мишљење и тако допринесу културном и економском напретку државе. У период у између два светска рата часописи и новине су представљали извор дневно актуелних информација из свих области друштвеног живота у земљи и свету. Велико залагање младих

1 Библиотека града Београда, Кнеза Михаила 56, Београд 11000 radmila.tasic@gmail.com

2 Рад је прерађен одломак докторске дисертације Омладинска међуратна периодика - студија и библиографија, одбрањене на Филолошком факултету у Београду 14. 7. 2016. године. 
окупљених око редакција часописа и њихова непрестана борба да очувају континуитет излажења покренутих наслова, сведочи о изузетном интересовању читалаца и великом значају омладинске периодике за социјални живот младих. Стицајем различитих околности ${ }^{3}$ мали број наслова је излажио више година. Омладински часописи и новине су предствљали простор за размену мишљења и сучељавања различитих идеја младих из свих крајева земље и иностранства. Уредници и власници омладинске периодике су били покретачи културне и просветне емаципације сеоске и градске, занатлијске и интелектуалне омладине тога доба. На њихову иницијативу организоване су радне акције 4 и екскурзије ${ }^{5}$ чији је циљ био упознавање и успостављање сарадње југословенске и свесловенске омладине.

\section{Улога омладинске периодике у јавном животу југословенске омладине између два светска рата}

Улога омладине у дефинисању националних циљева и интереса, остваривању социјалног и културног препорода, економког напретка, као и њени етички кодекси, понашање и начин живота, најчешће су разматране теме у омладинској међуратној периодици. Скоро да нема омладинског часописа чије уредништво не истиче да ће од образовања и васпитања младих зависити будућност земље. „Омладина је једини и најсигурнији израз тежњи и настојања сваког народа, зато је сасвим оправдано када се по вредности омладине цени и вредност нације." ${ }^{\prime}$ Од међуратне омладине се очекивало да преузме водећу улогу у развоју југословенског друштва. „Подизање националне културе, гајење родољубља, развијање култа словенске солидарности, припремање терена за узајамну сарадњу и друго све

3 Недостатак материјалних средстава, несугласице чланова редакције око уређивачке политике, ....

4 Теренско прикупљање сачуваног усменог народног књижевног стваралаштва, народних обичаја, рад на изградњи путева, школа и домова културе, копање одводних канала, пошумљавање голети и бројне друштвено-корисне активности

5 Уредништва часописа су често организовала екскурзије у циљу јачања интернационалне сарадње свесловенске омладине

6 Nikolić, Ljubiša. „Narod i omladina”. Narodna omladina: nezavisno glasilo jugoslovenske intelektualne omladine br. 4 (1934) : 1. 
су то задаци који се очекују од југословенске омладине". ${ }^{7}$ У нади да се ратне страхоте никада неће поновити и да ће разум преовладати у решавању постојећи друштвених и политичких проблема, омладина је настојала да послератни период искористи за изградњу једног новог и бољег друштва. У страху да се наследници Гаврила Принципа, Богдана Жерајића и других хероја из блиске им прошлости не одлуче за материјалне, а не духовне вредности, а прибојавајући се за будућност нације и земље, предратне генерације су упорно указивале на одавање пороцима, прихватање нових идеологија и лењост младих. „Идеали су ратом били срушени. Нови генији се нису појавили. Континуитет са предратним менталитетом био је прекинут. Друштво се изменило." ${ }^{8}$ Државни и национилани дисконтинуитет додатно је оптеретио јавни живот новоосноване земље. Омладина је лутала у потрази за новим иделаима желећи да искорени сваку врсту друштвене неједнакости. Традиционалне вредности су маргинализоване, а нови начин живота и понашања младих подстицао је егоизам, лењост и помодарство.

Предратна генерација је јавно изражавала искрено, дубоко и неподељено незадовољство понашањем и социјалним ангажовањем младих између два светска рата. „Најблажа карактеристика, која се данас галантно даје омладини састоји се обично из ових дивних оцена: мртва, љења, неспособна за живот, самовољна, разуздана, тврдоглава и бандоглава, а у изузетно отменом тону сматра се као неваспитана, испуштена и залутала." ${ }^{\prime}$ У време послератног полета старије генерације су веровале да ће њихови наследници својим делима показати да су достојни наследници својих предака. Убрзо почетни ентузијазам јењава, а омладинска периодика бележи, у почетку спорадично, а касније све бројније, оштре критике и велико незадовољство јавности социјалним ангажовањем омладине. „И поред безброј могућности за лично усавршавање, култивисање и напредовање, безнадно вене, пропада и умире у општој духовној

7 Trpković, Dušan M. „Na posao, Jugoslovenska omladino!” Južnoslovenska iskra : organ Južnoslovenske omladine br. 16 (1931): 4.

8 D. N. K. „Između barikada”. Narodna omladina : nezavisno glasilo jugoslovenske intelektualne omladine br. 8 (1934): 7.

9 M. "Stvarajmo svoju omladinsku samopomoć”. Južnoslovenska iskra : organ Južnoslovenske omladine. br. 16 (1931): 1. 
запарложености. Њу сатиру венеричне болести, давије алкохол, трује материјализам. Изгледа да ће се неповратно препустити разврату. Отуда није ни чудо што ова омладина није уопште способна за какав озбиљан рад, заснован на алтруизму, јер се сматра исувише реалном да би млатила празну сламу тамо где нема ништа у готовом"10. Старији не налазе оправдање за неодговорно понашање младих, као и за њихову незаинтересованост за укључивање у решавање бројних друштвених проблема. Социјално свесни омладинци покушавали су да својим делима демантују осуде јавности. Део омладине је поседовао социјалну свест о значају уређене државе и њених институција, обаразовању широких народних маса, економском напретку и личним примером указивао на потребе младих. „Снага омладине види се у корисном и интензивном раду и она се цени према способности сваког појединца. И према тој њеној снази и способности види се напредак народа, државе па и сваког појединог омладинца. Не каже се узалуд: Омладина је стуб државе. Зашто се највише омладини указује пажња и старање? Зато што ће душевна снага великих људи бити исцрпљена, а биће врло потребне нове снаге да чине нова дела. Тада долази омладина, у полету живота и почиње свој рад према коме се цени њена способност." 11 Истрошена константним политичким сукобима, деморалисана тешком економском ситуацијом, изложена утицају различитих идеја и партија, оптерећена великим очекивањима старијих генерација, међуратна омладина је покушава да пронађе свој пут у бурном времену између два светска рата.

Продор модерних, европских идеја утиче на понашање, стил и начин живота младих у градским срединама. На едукацију сеоске омладине утиче недостатак образовних и културних институција, па је, самим тим, већи значај омладинске периодике у просвећивању и културној еманципацији омладине. Између два рата започела је миграција сеоског становништва у градске средине. Од школоване сеоске омладине се очекивало да се по окончаном школовању врати на село и примени стечено знање. Увиђајући значај села у очувању традиционалних вредности и привредног напретка земље, на странама

10 Stanković, Dušan. „Uzroci neaktivnosti varoške omladine”. Južnoslovenska iskra : organ južnoslovenske omladine br. 6 (1930): 5.

11 Bitević, Živan D. „U čemu je snaga i koji su ideali omladine?”. Južnoslovenska iskra : organ Južnoslovenske omladine Novog pokreta br. 27 i 28 (1931),: 6. 
бројних међуратних омладинских часописа разматрани су актуелни проблеми који су утицали на миграцију сеоског становништва у градске средине. Објављивањем бројних прилога на тему односа сеоске и градске омладине, периодика је доприносила њиховом међусобном бољем разумевању и интензивнијој сарадњи.

Формирање јединствене државе створило је услове за шири културно-просветни развој. Одмах по завршетку рата отвара се велики број стручних школа опремљених лабораторијама, кабинетима, библиотекама и радионицама. Омладинска периодика бележи иницијативу предузимљивих појединаца да се у што већем броју, чак и у најмањим селима, отварају библиотеке и читаонице које су биле стецишта младих људи и центри културног живота. У средњим и основним школама између два светска рата учитељи су подстицали ученике да објављују своје књижевне радове у школским часописима.

Мато Ловрак, Новак Симић, Миодраг Ст. Стефановић, Јован Поповић, Илија Грбић, Никола Лопичић су представници књижевне струје која себе назива најмлађи. „Ако би могли да стегнемо контуре нашег послератног књижевног стварања, онда би га могли дати у једној краткој формули у којој би био садржан смисао његове трагедије: оно је еволуирало у социјалну књижевност, која је затим дегенерисала у марксизам."12 у предговору Антологије најновије литике Сима Пандуровић констатује да су „око 1922. године антиуметничке тенденције, упоредо са антикултурним и антидржавним покретима, биле страховито набујале." ${ }^{\prime 3}$ Сви омладински међуратни часописи, било да су књижевни или им је основна програмска оријентација другачија, објављивали су књижевно стваралаштво младих писаца. Стицајем различитих околности, већина младих књижевника који су своје прве радове објављивали, остали су непознати широј јавности. Промена друштвеног уређења 1945. године утицала је да њихова дела остану сачувана само у међуратној периодици. Марксистички оријентисани омладинци у Краљевини СХС агресивно промовишу социјално ангажовану књижевност. У жељи да југословенској јавности представе предности живота у социјалистичкој земљи, они преводе

12 Dragutinović, Vojislav. „Kratak osvrt na našu posleratnu književnost”. Nova Srbadija : časopis za sva omladinska pitanja br. 5 (1940): 257.

13 Milićević, Nika. „Dvije nove književne perspektive”. Mlada Bosna : omladinski pregled i književni zabavnik sv. 4 (1929): 86. 
руске, пропаганди намењене текстове. „Руска литература биће друкчије боје у будућности. Она ће можда изгубити нешто од своје тајанствености, заједно са искорењавањем руског празноверја (...) Руски народ је ослободио самог себе! Руски народ је пронашао самог себе!" 14 Извесно је да ни један народ не може сачувати свој културни и национални идентитет заборавивши своју прошлост и одрекавши се традиционалних и духовних вредности.

Омладински часописи између два светска рата промовишу рад као један од најважнијих предуслова за напредак и развој појединца и друштва. Од омладине се очекије да има позитиван став према раду. „Рад је наша главна парола, главно мерило личне вредности и једини доказ свести сваког омладинца. Тај рад мора да буде искрен и предан, дисциплинован и разуман, сталан и истрајан, не тражећи ни славе ни личне користи". ${ }^{15}$ Међуратна периодика је имала образовноваспитну улогу. Бројни прилози у часописима позивали су младе да буду социјално ангажовани и одговорни.

\section{Закључак}

Улогу омладинске међуратне периодике и њен значај за формирање животних ставова, етичких принципа, културног идентитета, националне и социјалне свести југословенске омладине тешко је свеобухватно сагледати и реално вредновати из перспективе савременог човека који живи у свету модерних комуникационих и информационих технологија. Омладински часописи и новине тога доба доносиле су вести о актуелним дешавањима у културном, политичком, економском и привредном животу земље. Они су имали велики утицај на формирање социјалне свести међуратне генерације која покушавала да превазђе тешке изазове са којима се суочила. Израда аналитичке и анотиране библиографије омладинске периодике између два светска рата омогућила је увид у различита интересовања и потребе међуратне омладине. Равномерна хронолошка и територијална заступљеност часописа у аналитичкој

14 R. „Narod koji je žedan znanja”. Jedro : omladinski književni časopis br. 3-4 (1924): 3. 15 Настављамо започето народно дело. У: Јужнословенска искра : орган јужнословенске омладине. - Год. 1, бр. 1 (15. јун 1930), стр. 1. 
библиографији ${ }^{16}$ пружа увид у сложене друштвено-политичке односе у земљи који су утицали на формирање Аличности младих у смутном времену препуном изазова.

\section{Литература}

Bitević, Živan D. „U čemu je snaga i koji su ideali omladine?”. Južnoslovenska iskra : organ Južnoslovenske omladine Novog pokreta br. 27 i 28 (1931),: 6.

D. N. K. „Između barikada”. Narodna omladina : nezavisno glasilo jugoslovenske intelektualne omladine br. 8 (1934): 7.

Dragutinović, Vojislav. „Kratak osvrt na našu posleratnu književnost”. Nova Srbadija : časopis za sva omladinska pitanja br. 5 (1940): 257.

M. „Stvarajmo svoju omladinsku samopomoć”. Južnoslovenska iskra : organ Južnoslovenske omladine. br. 16 (1931): 1.

Milićević, Nika. „Dvije nove književne perspektive”. Mlada Bosna : omladinski pregled i književni zabavnik sv. 4 (1929): 86.

Nikolić, Ljubiša. „Narod i omladina”. Narodna omladina : nezavisno glasilo jugoslovenske intelektualne omladine br. 4 (1934) : 1.

R. „Narod koji je žedan znanja”. Jedro : omladinski književni časopis br. 3-4 (1924): 3.

Stanković, Dušan. „Uzroci neaktivnosti varoške omladine”. Južnoslovenska iskra : organ južnoslovenske omladine br. 6 (1930): 5.

Trpković, Dušan M. „Na posao, Jugoslovenska omladino!” Južnoslovenska iskra : organ Južnoslovenske omladine br. 16 (1931): 4.

16 Изабрани часописи су излазили у Београду, Загребу, Сарајеву, Вршцу и Паризу од 1918. до 1941. године 
Radmila N. Tasić

\section{CULTURAL AND NATIONAL IDENTITY YUGOSLAV YOUTH IN THE MIRROR ANALYTICAL BIBLIOGRAPHY YOUTH INTERWAR PERIODICALS}

\section{Summary}

Doctoral disertation Youth interwar periodicals - studies and bibliography presents scientific and professional public priceless wealth of information about the life and work of the young people of that era. There are chronological, formal and content presented all available addresses youth interwar periodicals at the Serbo-Croatian language. Analytical and annotated bibliography youth interwar periodicals contributed to the completion of the national analytical bibliography.

Keywords: youth periodicals, analytical bibliography, yugoslav idea, national identity 